\title{
PENERAPAN HASIL RISET MELALUI APLIKASI ABDIMAS
}

\author{
${ }^{1}$ Rahmadini Darwas, ${ }^{2}$ Vivi Meldya Saputri \\ ${ }^{1,2}$ Sistem Informasi, STMIK Indonesia Padang, Jl. Khatib Sulaiman Dalam No. 1 Padang \\ Email: dini@stmikindonesia.ac.id, vivimeldya123@gmail.com
}

(Diterima: 6 Februari 2019, direvisi: 22 Juli 2019, disetujui: 6 Agustus 2019)

\begin{abstract}
ABSTRAK
Penelitian dan pengabdian masyarakat merupakan salah satu Tri Dharma Perguruan Tinggi yang wajib dilakukan seorang dosen. Keterlibatan dosen sebagai peneliti dan pengabdi masyarakat merupakan salah satu upaya dalam mencerdaskan bangsa. Tujuan penelitian ini adalah untuk menfasilitasi peneliti khususnya dosen STMIK Indonesia Padang dalam menyebarluaskan hasil-hasil penelitian yang dapat digunakan masyarakat. Kurangnya informasi bagi dosen untuk melakukan pengabdian masyarakat berdasarkan hasil penelitian yang sesuai dengan kebutuhan masyarakat menjadi kendala yang terjadi saat ini sehingga penelitian yang telah dilakukan belum dapat diimplementasikan secara optimal. Selain itu, masyarakat juga mengalami kendala dalam hal mendapatkan informasi terkait dengan hasil riset yang sesuai dengan kebutuhan di lapangan. Metode yang digunakan dalam penelitian ini adalah metode berorientasi objek menggunakan alat bantu perancangan sistem Unified Modeling Language (UML). Penelitian ini meghasilkan aplikasi abdimas yang mampu menjembatani hasil-hasil riset peneliti dengan kebutuhan masyarakat.
\end{abstract}

Keywords: riset, abdimas, UML

\section{PENDAHULUAN}

Dalam Undang-undang Republik Indonesia Nomor 14 Tahun 2005 tentang Guru dan Dosen, pasal 1 ayat 2 dinyatakan bahwa dosen adalah pendidik profesional dan ilmuwan dengan tugas utama mentransformasikan, mengembangkan, dan menyebarluaskan ilmu pengetahuan, teknologi, dan seni melalui pendidikan, penelitian, dan pengabdian masyarakat. Penelitian dan pengabdian masyarakat merupakan salah satu Tri Dharma Perguruan Tinggi yang wajib dilakukan seorang dosen. Keterlibatan dosen sebagai peneliti dan pengabdi masyarakat merupakan salah satu upaya dalam mencerdaskan bangsa [1]. Kegiatan pengabdian kepada masyarakat merupakan penerapan, pengalaman dan membudayakan ilmu pengetahuan dan teknologi [2]. Hasil-hasil riset yang dilakukan harus memiliki manfaat yang baik bagi masyarakat [3]. Kurangnya informasi bagi dosen untuk melakukan pengabdian masyarakat menjadi kendala yang terjadi saat ini sehingga penelitian yang telah dilakukan belum dapat diimplementasikan secara optimal. Oleh karena itu diperlukan suatu interaksi antara peneliti dan masyarakat sehingga penelitian yang dihasilkan sesuai dengan kebutuhan masyarakat. Untuk menjembatani interaksi antara peneliti dan masyarakat dibangun suatu aplikasi abdimas berbasis web. Aplikasi ini merupakan suatu wadah yang dapat memudahkan masyarakat untuk menemukan hasil penelitian dosen yang dapat mengatasi permasalahan yang sedang dihadapi masyarakat.

\section{TINJAUAN PUSTAKA}

Beberapa penelitian terdahulu yang sudah pernah dilakukan diantaranya penelitian yang dilakukan oleh [4] menyatakan bahwa rendahnya perekonomian masyarakat di daerah, menyebabkan kurangnya kepedulian masyarakat untuk membaca dan kurangnya sarana dan prasarana untuk menunjang kegiatan membaca. Dengan adanya e-library dapat memfasilitasi para penulis lokal untuk menyebarkan hasil karya mereka di masyarakat [5]. Penelitian beikutnya dilakukan oleh [6] menyatakan bahwa aplikasi administrasi pengelolaan penelitian dan pengabdian masyarakat berbasis web di Institut Bisnis dan Informatika STIKOM Surabaya dapat membantu dalam pengelolaan data kegiatan penelitian dan pengabdian masyarakat. 
Penelitian selanjutnya dilakukan oleh [7] menyatakan bahwa unit penelitian dan pengabdian pada masyarakat di Universitas Respati Yogyakarta mengalami permasalahan dalam proses pengolahan data kegiatan penelitan dan pengabdian pada masyarakat. Masalah yang dihadapi disebabkan karena belum adanya basis data yang digunakan untuk pengumpulan data terkait rekam jejak kegiatan penelitian dan pengabdian masyarakat. Penelitian tersebut bertujuan untuk mengembangkan sistem informasi yang dapat melakukan proses pengolahan data penelitian dan pengabdian kepada masyarakat. Penelitian ini menghasilkan rancang bangun sistem dan implementasi yang telah dilakukan mampu melakukan pengolahan rekam jejak kegiatan penelitian dan pengabdian masyarakat oleh dosen.

\section{METODOLOGI PENELITIAN}

Ruang lingkup atau objek dari penulisan ini yaitu (a) dosen STMIK Indonesia dan masyarakat umum (b) rancangan meliputi input artikel penelitian oleh dosen, input pengabdian oleh masyarakat, dan pencarian artikel sehingga menampilkan permohonan pengabdian dan hasil pengabdian. Penelitian ini dilakukan di STMIK Indonesia Padang. Metode penelitian dalam pengembangan perangkat lunak yang digunakan adalah metode berorientasi objek yang merupakan suatu strategi pembangunan perangkat lunak sebagai kumpulan objek yang berisi data dan operasi yang diberlakukan terhadapnya [8]. Tahapan-tahapan yang dilakukan adalah :

a. Analisis berorientasi objek (object oriented analysis)

Menganalisa proses berorientasi objek yang diperlukan dengan sistem serta keterkaitannya [9]. Tujuannya adalah untuk memahami sistem yang akan dibangun.

b. Desain berorientasi objek (Object oriented design)

Merupakan tahapan lanjutan setelah analisis berorientasi objek dimana tujuan sistem diorganisasikan ke dalam sub sistem berdasar struktur analisis dan arsitektur yang dibutuhkan [10]. Desain berorientasi objek menggunakan Unified Modeling Language (UML). UML merupakan metodologi untuk mengembangkan sistem program berorientasi objek dan seperangkat tool untuk mendukung pengembangan sistem tersebut [11]. Rancangan sistem ini akan digambarkan dalam bentuk use case diagram dan activity diagram. Use case diagram menampilkan fungsi apa saja yang dapat dilakukan oleh user [12]. Activity diagram menggambarkan workflow (aliran kerja) atau aktivitas dari sebuah sistem atau proses bisnis [13].

c. Pemrograman berorientasi objek

Penelitian ini menggunakan bahasa pemrograman Hypertext Preprocessor (PHP). PHP merupakan bahasa pemrograman yang digunakan secara luas untuk penanganan pembuatan dan pengembangan sebuah web dan biasa digunakan pada HTML [14]

d. Pengujian berorientasi objek

Mengaplikasikan dan menguji fungsi-fungsi apakah berjalan dengan baik dan memastikan aplikasi siap diimplementasikan. Pengujian dilakukan untuk meminimalisir kesalahan (error) dan memastikan keluaran yang dihasilkan sesuai dengan yang diinginkan [15].

\section{HASIL DAN PEMBAHASAN}

\subsection{Hasil}

\section{a. Use Case Diagram Dosen}

Pada aplikasi abdimas ini menggunakan dua actor yaitu dosen dan masyarakat. Untuk mengetahui interaksi apa saja yang dilakukan antara user dengan aplikasi dan fungsi apa saja yang dapat dilakukan user dapat dilihat pada Gambar 1. 


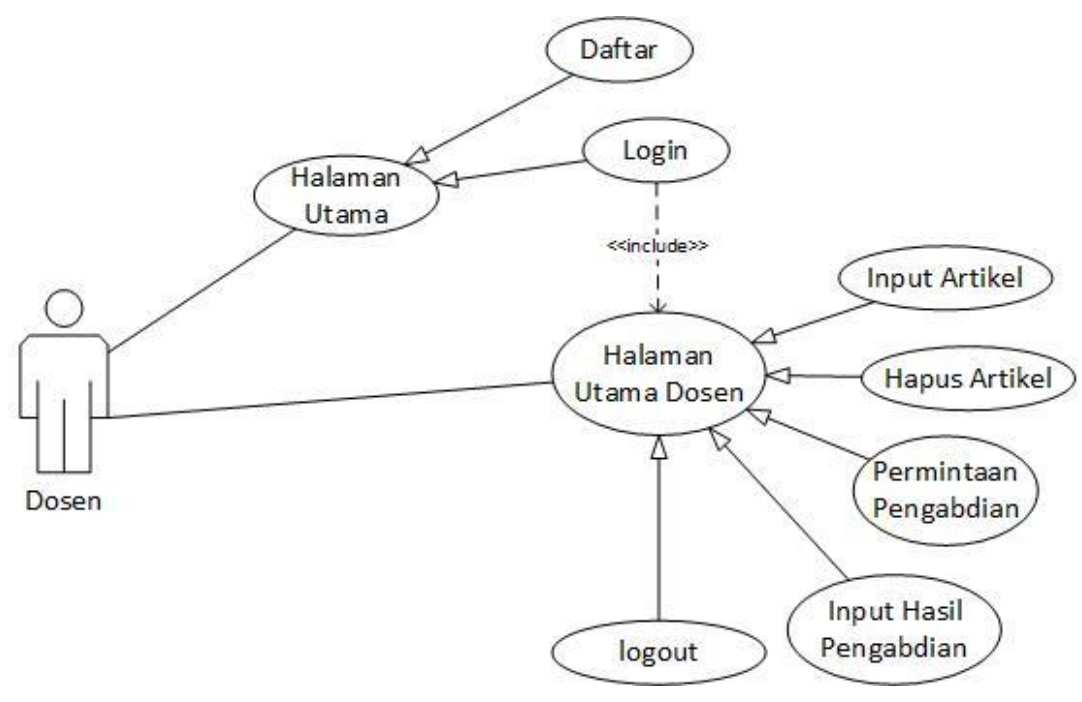

Gambar 1 Use case diagram dosen

Gambar 1 menjelaskan interaksi antara dosen dengan aplikasi. Dosen membuka halaman utama untuk mendaftar agar dapat login ke halaman dosen. Setelah dosen login dan masuk ke halaman utama, maka dosen dapat memilih menu yang telah tersedia. Seperti dasboard, input artikel, hapus artikel, lihat permintaan pengabdian, input hasil pengabdian. Setelah selesai, dosen dapat logout ke halaman utama web.

b. Use Case Diagram Masyarakat

Interaksi serta fungsi-fungsi yang dapat dilakukan oleh masyarakat ditunjukkan pada Gambar 2.

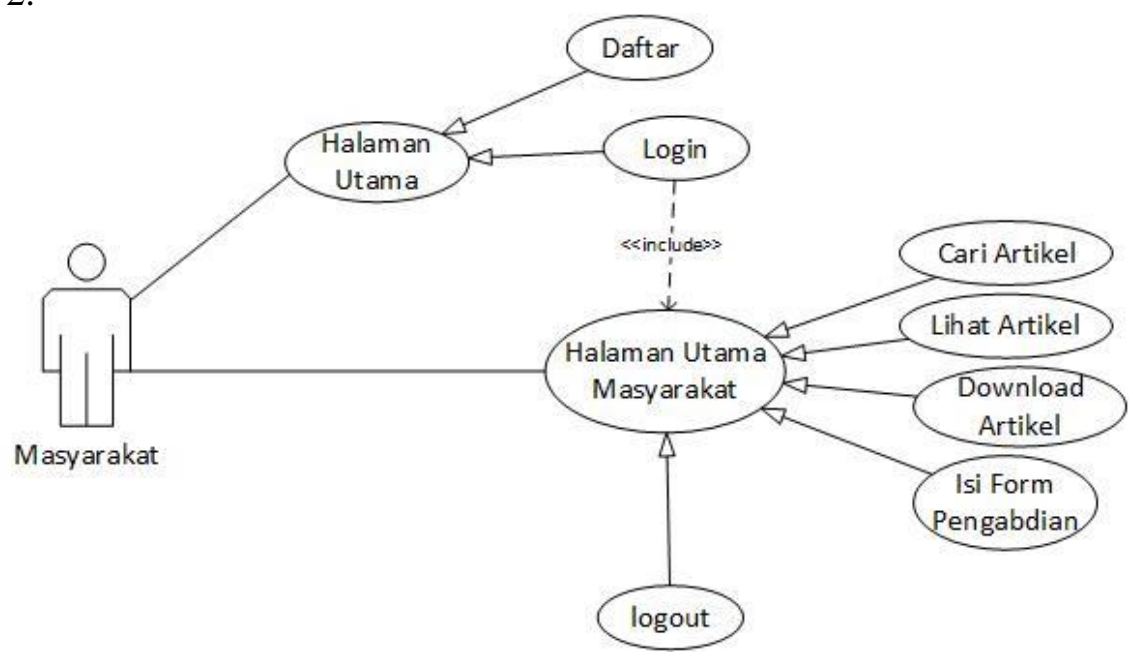

Gambar 2 Use case diagram masyarakat

Gambar 2 menjelaskan bahwa pada saat masyarakat login, masyarakat dapat melihat kumpulan artikel dosen, pencarian artikel, dan download artikel. Jika masyarakat sudah menemukan artikel yang sesuai dengan kebutuhan, maka dapat mengisi form pengabdian

c. Activity Diagram input artikel

Activity diagram menggambarkan aktivitas dan tindakan yang dapat dilakukan oleh sistem. Activity diagram input artikel dapat dilihat pada Gambar 3. 


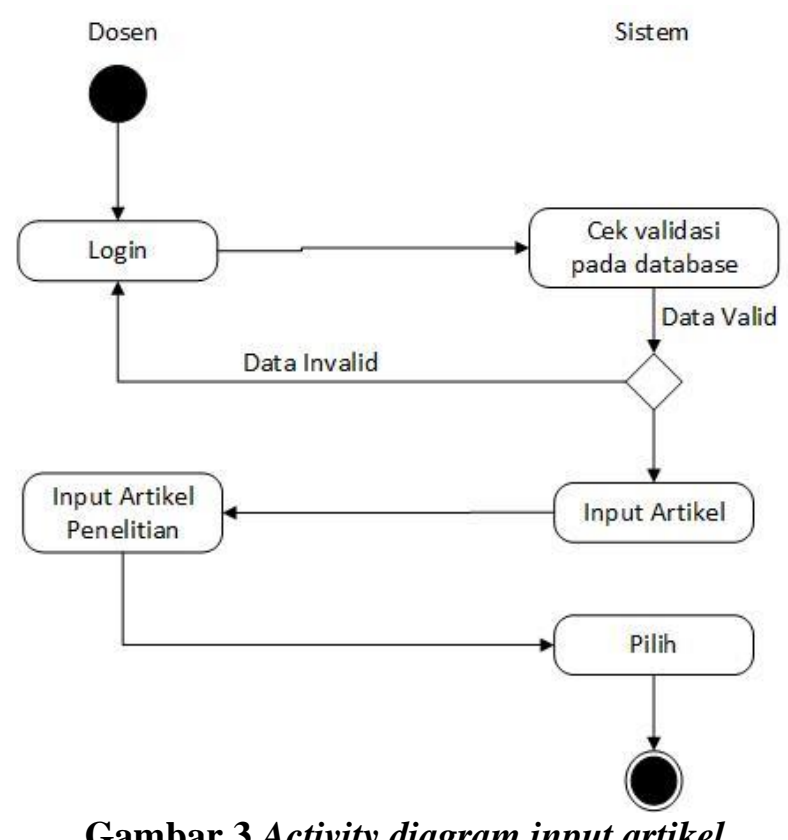

Gambar 3 Activity diagram input artikel

Gambar 3. menjelaskan aktivitas yang dilakukan oleh sistem terhadap dosen. Pada saat dosen login, sistem akan melakukan pengecekan validasi data. Jika data yang diinputkan valid maka sistem akan memberikan akses kepada dosen untuk melakukan input artikel penelitian.

d. Activity Diagram Cari Artikel

Activity Diagram Cari Artikel dapat dilihat pada Gambar 4.

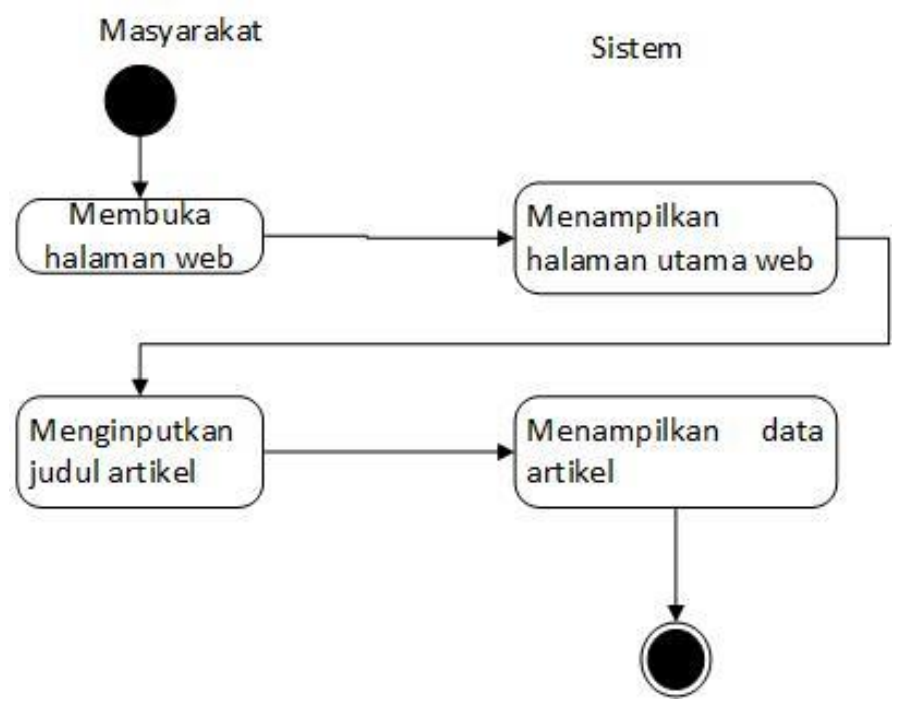

\section{Gambar 4 Activity diagram cari artikel}

Gambar 4. menjelaskan bahwa sistem akan menampilkan halaman utama web pada saaat masyarakat membuka halaman web tersebut. Dan sistem akan menampilkan artikel berdasarkan judul artikel yang telah diinputkan oleh masyarakat.

e. Activity Diagram Permohonan Pengabdian

Activity Diagram Permohonan Pengabdian dapat dilihat pada Gambar 5.

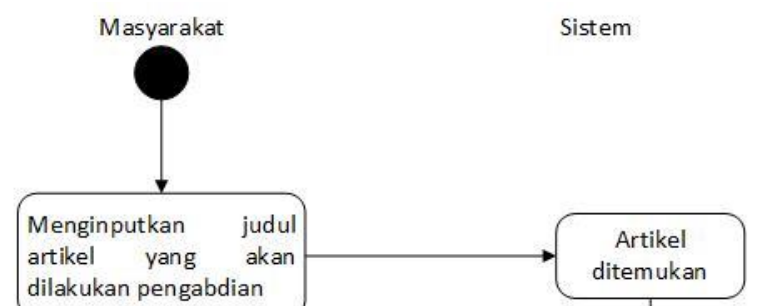




\section{Gambar 5 Activity diagram permohonan pengabdian}

Gambar 5. menjelaskan bahwa sistem akan menampilkan artikel penelitian yang dicari oleh masyarakat dan masyarakat dapat mendownload artikel tersebut. Jika masyarakat membutuhkan artikel tersebut untuk diimplementasikan maka masyarakat dapat mengisi form pengabdian dan sistem akan mengirimkan data masyarakat ke email peneliti.

f. Halaman Utama Aplikasi Abdimas

Halaman utama website merupakan tampilan awal dan tampilan utama dari aplikasi abdimas ini. Halaman ini, dapat diakses oleh siapapun yang membuka website abdimas ini. Tampilan dari halaman utama website, ditunjukkan pada Gambar 6.

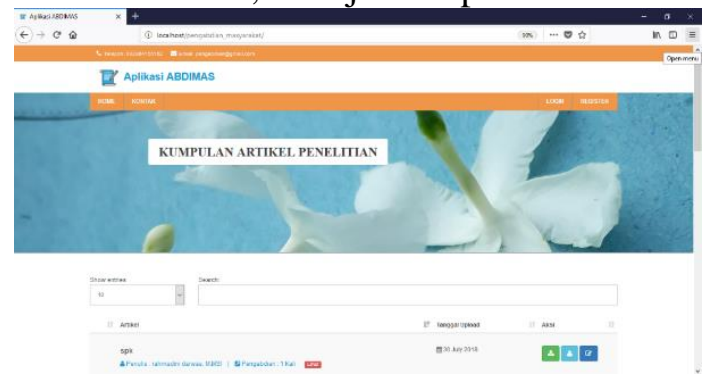

Gambar 6 Halaman utama aplikasi abdimas

Gambar 6. merupakan bentuk dari tampilan awal dari website abdimas ini dibuka. Pada halaman utama ini, user dapat melakukan berbagai aktifitas yang diinginkannya. Seperti register, login, melihat artikel penelitian, download artikel penelitian, melihat profil penulis artikel penelitian dan melihat menu kontak pada website abdimas ini.

\section{g. Download Artikel}

Download artikel merupakan tempat dimana masyarakat bisa mendownload artikel penelitian yang ada dalam website. Tampilan download artikel ditunjukkan pada Gambar 7. 


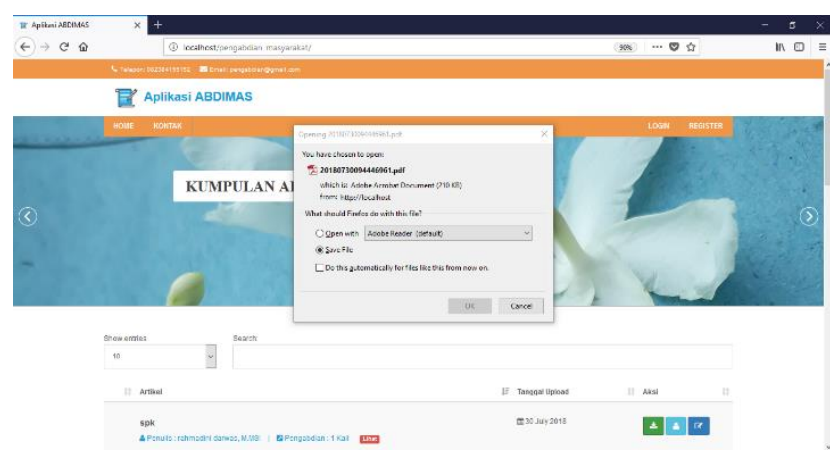

Gambar 7 Download artikel

h. Permohonan Pengabdian

Permohonan pengabdian merupakan tempat dimana dosen dapat melihat permohonan pengabdian yang masuk, menyetujui permohonan, melihat profil pemohon dan menghapus permohonan. Tampilan dari list permohonan pengabdian ditunjukkan oleh Gambar 8 .

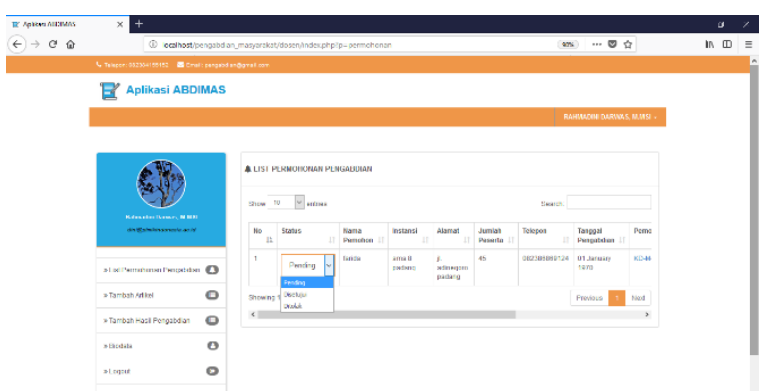

Gambar 8 Permohonan pengabdian

\subsection{Pembahasan}

Aplikasi abdimas menampilkan fitur-fitur yang dapat menjembatani peneliti dengan masyarakat. Hal ini ditunjukkan dengan adanya fitur permohonan pengabdian yang dilakukan masyarakat. Masyarakat dapat mencari artikel penelitian yang dilakukan dosen dan mendownload artikel tersebut yang sesuai dengan kebutuhan. Selain itu masyarakat dapat meminta dosen untuk mengimplementasikan penelitian tersebut dalam bentuk pengabdian masyarakat. Berdasarkan impelementasi yang telah dilakukan, aplikasi ini berjalan sesuai dengan analisis dan pengembangan yang direncanakan. Pengujian aplikasi yang telah dikembangkan ditunjukkan pada Tabel 1.

Tabel 1 Pengujian Sistem

\begin{tabular}{llll}
\hline No & \multicolumn{1}{c}{ Pengujian } & \multicolumn{1}{c}{ Keterangan } & Hasil \\
\hline 1 & Cari artikel & $\begin{array}{l}\text { Mencari judul artikel sesuai yang } \\
\text { diinputkan }\end{array}$ & Suskses \\
\hline $\mathbf{2}$ & Download artikel & $\begin{array}{l}\text { Mendownload artikel yang ada } \\
\text { pada halaman utama web }\end{array}$ & Suskses \\
\hline $\mathbf{3}$ & Lihat profil & $\begin{array}{l}\text { Lihat profil peneliti artikel yang } \\
\text { ada pada halaman utama web }\end{array}$ & Suskses \\
\hline $\mathbf{4}$ & Register & $\begin{array}{l}\text { Registrasi data dosen maupun } \\
\text { masyarakat }\end{array}$ & Suskses \\
\hline $\mathbf{5}$ & Login & Login dosen maupun masyarakat & Suskses \\
\hline $\mathbf{6}$ & Upload artikel & $\begin{array}{l}\text { Menginputkan data artikel dan file } \\
\text { artikel yang akan di publish }\end{array}$ & Suskses \\
\hline
\end{tabular}




\begin{tabular}{llllll}
\hline $\mathbf{7}$ & $\begin{array}{l}\text { Tambah artikel, hapus dan } \\
\text { edit }\end{array}$ & $\begin{array}{l}\text { Menambah artikel, mengedit dan } \\
\text { menghapus artikel yang pernah di } \\
\text { upload sebelumnya }\end{array}$ & Suskses \\
\hline $\mathbf{8}$ & $\begin{array}{l}\text { Lihat permohonan } \\
\text { pengabdian,menyetujui } \\
\text { permohohonan dan profil } \\
\text { pemohon }\end{array}$ & $\begin{array}{l}\text { melihat permohonan pengabdian, Suskses } \\
\text { menyetujui dan profil pemohon } \\
\text { dalam menu list permohonan } \\
\text { pengabdian }\end{array}$ & \\
\hline $\mathbf{9}$ & Input hasil pengabdian & $\begin{array}{l}\text { Menginputkan data dan } \\
\text { dokumentasi pengabdian yang } \\
\text { telah dilakukan }\end{array}$ & Suskses \\
\hline $\mathbf{1 0}$ & Biodata & $\begin{array}{l}\text { Mengedit data biodata dosen } \\
\text { maupun masyarakat }\end{array}$ & Suskses \\
\hline $\mathbf{1 1}$ & Permohonan pemngabdian & $\begin{array}{l}\text { Mengirimkan permohonan } \\
\text { pengabdian ke e-mail pemilik } \\
\text { artikel Suskes }\end{array}$ & \\
\hline $\mathbf{1 2}$ & Profil pemohon & $\begin{array}{l}\text { Melihat profil pemohon } \\
\text { pengabdian }\end{array}$ & Suskses \\
\hline
\end{tabular}

\section{KESIMPULAN}

Aplikasi abdimas sebagai jembatan yang menghubungkan peneliti (dosen) dan masyarakat. Melalui aplikasi abdimas ini, dosen dapat dengan mudah melakukan pengabdian kepada masyarakat yang merupakan salah satu bentuk tri dharma Perguruan Tinggi. Penelitian yang dilakukan dosen dapat diimplementasikan secara optimal di masyarakat dan sesuai dengan kebutuhan masyarakat. Disamping itu, aplikasi ini juga membantu dalam memecahkan permasalahan yang terjadi di masyarakat.

\section{UCAPAN TERIMA KASIH}

Penulis mengucapkan terima kasih kepada Yayasan Amal Bakti Mukmin Padang dan STMIK Indonesia Padang yang telah memberikan dukungan finansial terhadap penelitian ini dengan nomor kontrak 005/K.A/LPPM/STMIK-I/2018.

\section{REFERENSI}

[1] A. S. Kurniawansyah, J. Wahyudi, and R. Julita, "Membangun Sistem Pendukung Keputusan Untuk Menentukan Dosen Berprestasi Di Prodi Informatika Fakultas Ilmu Komputer Universitas Dehasen Bengkulu," J. Media Infotama, vol. 15, no. 1, pp. 44-49, 2019.

[2] T. Suryani, "Penguatan dan Peran Perguruan Tinggi dalam Pemberdayaan Masyarakat di Era Industri 4.0," in Seminar Nasional Hasil Pengabdian kepada Masyarakat, 2018, no. 2013, pp. $1-6$.

[3] A. I. Benardi and S. Putro, "Pelatihan Penulisan Publikasi Jurnal Ilmiah Terakreditasi Nasional Bagi Guru Di Mgmp," J. Panjar, vol. 1, no. 1, pp. 50-54, 2019.

[4] A. Prayitno and Y. Safitri, "Pemanfaatan Sistem Informasi Perpustakaan Digital Berbasis Website Untuk Para Penulis," Indones. J. Softw. Eng., vol. 1, no. 1, pp. 1-10, 2015.

[5] Haryanto, "Inovasi Perpustakaan Sebuah Tantangan Kualitas Layanan Publik," Wineka Media, 2019 , p. 112.

[6] N. Maya Sari, T. Wurijanto, and J. Lemantara, "Rancang Bangun Aplikasi Administrasi ( Studi Kasus Institut Bisnis Dan Informatika,” J. Sist. Inf. Komput. Akunt., vol. 5, no. 7, pp. 1-7, 2016.

[7] Hamzah, "Sistem Informasi Kegiatan Penelitian dan Pengabdian Kepada Masyarakat Universitas Respati Yogyakarta,” Teknosi, vol. 2, no. 2, 2016.

[8] H. Rasminto and A. Ari Kuncoro, "Perancangan Sistem Informasi Penggunaan Dana Bantuan Operasional Sekolah Terpadu Dengan Metode Berorientasi Objek," in Seminar Nasional Edusaintek, 2018, pp. 242-252. 
[9] Nelfira, Z. Efendy, and I. Putra Tanjung, "Aplikasi Pembelajaran Generasi Berencana pada Pusat Informasi dan Konseling Remaja Gerami Naungan BKKBN Sumatera Barat," Indones. J. Comput. Sci., vol. 6, no. 1, pp. 31-47, 2017.

[10] E. Mulyana, F. Abdurahim, M. A. Ramdhani, and O. Taupikurahman, "Analisis dan Perancangan Arsitektur Sistem Aplikasi Layanan Informasi Lokasi Berbasis IoT," in Seminar Nasional Teknik Elektro, 2018, pp. 243-252.

[11] S. Santoso, Hamsyah, and A. Firmansyah, "Aplikasi Monitoring Rumah Kos Berbasis Android," J. Maklumatika, vol. 5, no. 2, pp. 129-139, 2019.

[12] D. I. Dinas, P. Rakyat, and P. Dan, "Perancangan Dashboard Sebagai Sistem Informasi Di Dinas Perumahan Rakyat, Pemukiman Dan Pertamanan Kota Batam," J. Responsive, vol. 2, no. 2, pp. 123-133, 2018.

[13] H. F. Siregar, Y. H. Siregar, and Melani, "Perancangan Aplikasi Komik Hadist Berbasis Multimedia," J. Teknol. Inf., vol. 2, no. 2, pp. 113-121, 2018.

[14] R. Wulandari, Danuri, and Jaroji, "Aplikasi Pengelolaan Presensi Guru Berbasis Web Di Dinas Pendidikan Kabupaten Bengkalis," J. Inform. Polinema, vol. 5, no. 3, pp. 165-170, 2019.

[15] Hardiyanto, Abdussomad, E. Haryadi, R. Sopandi, and Asep, "Penerapan Model Waterfall Dan Uml Dalam Rancang Bangun Program Pembelian Barang Berorientasi Objek Pada PT. Fujita Indonesia," J. Interkom, vol. 13, no. 4, 2019. 